\title{
IDENTIFICATION OF RICE GENOTYPES RESISTANT TO BACTERIAL LEAF BLIGHT DISEASE USING SSR MARKERS
}

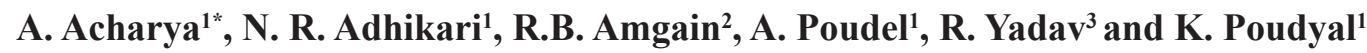 \\ ${ }^{1}$ Institute of Agriculture and Animal Science, Tribhuvan University, Nepal \\ ${ }^{2}$ Nepal Agricultural Research Council \\ ${ }^{3}$ Agriculture and Forestry University, Rampur, Chitwan, Nepal \\ *acharyarun15@gmail.com
}

\begin{abstract}
Bacterial blight disease of rice is a growing and challenging concern in Nepal. Since bacterial pathogen (Xanthomonas oryzae pv. oryzae) is difficult to manage by other means effectively, development of host plant resistance is the most effective mean to control this disease. This study was carried out to identify the bacterial leaf blight resistant genotypes of rice by using of molecular markers linked with bacterial blight resistant genes. Sixty genotypes of rice were screened at glass house for BB resistance and they were tested for the presence of Xa4, Xa5, Xa7 and Xa21 genes using markers MP, RM122, M5 and pTA248 respectively. IRBB 60 and Jumli Marshi were used as resistant and susceptible check respectively. Twenty five genotypes of rice were detected with presence of Xa4 gene, 24 genotypes with Xa5 gene and fourteen genotypes with Xa7 gene. Twenty four genotypes did not showed presence of any gene. Twenty four genotypes showed the presence of more than one gene with the specific molecular markers. Almost all genotypes that did not show presence of any gene were found highly susceptible in greenhouse conditions with both inoculums. Genotypes having more than one BB resistance gene were found resistant in greenhouse conditions with both inoculums suggesting combination of BB resistance gene through gene pyramiding will provide BB resistant varieties in rice breeding.
\end{abstract}

Key words: BB, Gene, Markers, Pyramiding, Resistance.

\section{INTRODUCTION}

Rice (Oryza Sativa) is one of the major cereals of the world. It is the staple food of about $60 \%$ of the world's population. More than $90 \%$ of the rice is produced and consumed in Asia (Singh et al., 2001). In Nepal it is ranked top most cereal with total area 13, 62, 908 hectare and productivity of 3.15 tons per hectare (MoAD, 2072/73). Rice production is limited by both biotic and abiotic stresses. Diseases are the main cause of loss in productivity of rice. Bacterial leaf blight of rice is caused by Xanthomonas oryzae pv. oryzae (Swings et al., 1990). It causes high yield losses up to $20 \%$ to $80 \%$ worldwide (Exconde et al., 1993). In Nepal it is second most serious rice disease after blast averaging 26\% yield loss (Adhikari and Mew, 1992).

Bacterial blight resistant varieties are in great demand in the context of damages caused by the disease. Due to the ineffectiveness of the chemicals, their abundance and relation to cost, search for host plant resistance is the current issue. Globally 38 resistance genes are identified with tightly linked markers (Bhasin et al., 2012). Primers tightly linked to genes of interest are probably the most attractive markers since no further manipulations are needed for implementation. Yet, many genotypes are to be known about their response towards bacterial blight and in Nepal, only few released varieties are known to be resistant. Simple Sequence Repeat (SSR) markers are 2-6 base pairs (bp) repetitive sequence of nucleotide with known position. Identification of genotypes showing gene presence as amplified by specific markers and their response in greenhouse would be more reliable than alone to identify BB resistance genotypes of rice. 


\section{MATERIALS AND METHODS}

Sixty genotypes of rice were collected for this study, 9 released varieties, 23 advanced lines of Jumli Marshi and IR 64 (referred as, JumliMarshi/IR64//JumliMarshi-(1-25)), 22 International Rice Research Institute (IRRI) lines and 6 Nepalese rice (NR) lines. Both molecular study and greenhouse screening was done in the premises of Nepal Agriculture Research Council (NARC), Biotechnology division, Lalitpur, Nepal. Jumli Marshi and IRBB 60 were used as susceptible and resistant check respectively.

\section{Genomic DNA extraction and quantification}

A young leaf from incubated seeds $\left(29^{\circ} \mathrm{C}\right.$ for 2 weeks $)$ of each genotype was grinded by mortar and pestle using liquid nitrogen. Genomic DNA was prepared using modified CTAB method as described by Sul and Kurban. DNA concentration was determined using spectrophotometer (Beckman DU-65) and adjusted to 50 nano gram (ng) for dilution.

Table 1: Molecular markers used to identify the presence of BB resistance genes

\begin{tabular}{|c|c|c|c|c|c|}
\hline $\begin{array}{l}\text { Marker } \\
\text { name }\end{array}$ & Type & Forward sequence $5^{\prime} \rightarrow 3^{\prime}$ & Reverse sequence & Gene & Reference \\
\hline MP & SSR & ATCGATCGATCTTCACGAGG & TCGTATAAAAGGCATTCGGG & Xa4 & $\begin{array}{l}\text { Chen et al., } \\
1997 \text { Ma et } \\
\text { al., } 1999 \mathrm{Mc} \\
\text { Couch et al., } \\
\text { 2002) }\end{array}$ \\
\hline RM 122 & SSR & GAGTCGATGTAATGTCATCAGTGC & GAAGGAGGTATCGCTTTGTTGGAC & $\mathrm{Xa} 5$ & $\begin{array}{l}\text { Chen et al., } \\
1997\end{array}$ \\
\hline M5 & SSR & CGATCTTACTGGCTCTGCAACTCTGT & GCATGTCTGTGTCGATTCGTCCGTACGA & Xa7 & $\begin{array}{l}\text { Porter et al., } \\
2003\end{array}$ \\
\hline pTA 248 & STS & AGACGCGGAAGGGTGGTTTCCCGGA & AGACGCGGTAATCGAAAGATGAAA & $\mathrm{Xa} 21$ & $\begin{array}{l}\text { Huang et al., } \\
1997\end{array}$ \\
\hline
\end{tabular}

\section{Polymerase Chain Reaction}

$100 \mathrm{ng}$ of genomic DNA, 1 micro mole $(\mu \mathrm{M})$ of each primer and 7.5 micro litre $(\mu \mathrm{l})$ of PCR Master Mix (Promega Corporation, Madison, WI, USA). PCR mixture was amplified in MJ Research PTC-100TM Programmable Thermal Controller with the temperature regimes: initial denaturation for $2 \mathrm{~min}$ at $95^{\circ} \mathrm{C}$ followed by 33 cycles of $95^{\circ} \mathrm{C}$ for $30 \mathrm{sec}$, annealing as per primer for $1 \mathrm{~min}$, extension at $72^{\circ} \mathrm{C}$ for $2 \mathrm{~min}$ and final extension at $72^{\circ} \mathrm{C}$ for $7 \mathrm{~min}$ followed by holding at $4{ }^{\circ} \mathrm{C}$.

\section{Gel Electrophoresis and data analysis}

Amplified PCR products was separated in 2\% analytical grade agarose gel at $100 \mathrm{~V}$ for 1 hour with $1 \mathrm{x}$ TAE buffer and detected by staining with ethidium bromide. It was visualized under UV transilluminator gel documentation system using $1 \mu$ g guide size DNA ladder (Thermofisher Ltd). The presence and absence of particular band size was scored for screening disease resistance genes. The amplified products were scored as bands on visualization on gel on UV illuminator. Only the reliable bands were included in analysis. These scored bands were computed into binary matrix. The presence of the corresponding resistant band was scored as " 1 " and absent bands was scored as " 0 ".

\section{Preparation of media and inoculums}

Media was prepared of peptone (1.2\%), sucrose $(1.2 \%)$ and agar $(2 \%)$. Inoculums were collected from Hardinath, Dhanusha (inoculum-1) and Surunga, Jhapa (inoculum-2) from Dharwar dry and highly susceptible variety respectively. 


\section{Growing of rice seedlings and disease assessment}

Rice seeds of each genotype were sown in plastic pots (10 inches diameter) @ 10 grains/ pot and were covered with thin layer of soil with required irrigation in greenhouse. Inoculation was done at 21 days old seedlings with the help of scissors. The observations regarding the occurrence of bacterial leaf blight disease was taken by using the standard procedure developed by International Rice Research Institute (IRRI, 1996).

Table 2: Disease assessment using rating scale

\begin{tabular}{cll}
\hline Disease rating scale & Lesion (affected area) area on leaf $(\%)$ & Category \\
\hline 1 & $1-5$ & Resistant \\
3 & $6-12$ & Moderately resistant \\
5 & $13-25$ & Moderately susceptible \\
7 & $26-50$ & Susceptible \\
9 & $51-100$ & Highly susceptible \\
\hline
\end{tabular}

\section{RESULTS AND DISCUSSION}

$\mathrm{BB}$ disease continues to cause huge losses worldwide in rice production due to reliance on cultivars with race-specific resistance and the high level of virulence variation in pathogens. A new approach which is based on the widespread conventional selection with the use of information from the molecular markers will facilitate breeding program through better combination of cost, time, precision and durability. Marker assisted screening (MAS) is successful and innovative breeding tool in this context.

Markers used in this study MP1, RM 122, M5 and pTA 248 respectively were for genes $\mathrm{Xa} 4, \mathrm{Xa} 5, \mathrm{Xa} 7$ and Xa21 showing their presence in rice genotypes. Twenty five genotypes of rice were detected with presence of Xa4 gene, 24 genotypes with Xa5 gene and 14 genotypes with Xa7 gene. Twenty four genotypes did not showed presence of any gene. Thirteen genotypes showed the presence of Xa4 and Xa5 gene, 5 showed the presence of Xa4 and Xa7 gene, 3 genotypes were found to detect the presence of Xa5 and Xa7 gene and 3 genotypes showed the presence of Xa4, Xa5 and $\mathrm{Xa} 7$ gene with the specific molecular markers. The response of the genotypes when screened in greenhouse conditions using two inoculums were different regarding presence of gene and resistance in greenhouse and vice versa.

Greenhouse screening of the studied genotypes of rice revealed the genotypes in different categories according to the percentage of affected area in leaf. Twenty eight genotypes were found resistant, 3 moderately resistant, 2 moderately susceptible, 2 susceptible and 22 genotypes highly susceptible. Almost all genotypes which did not showed the presence of any gene in marker assisted screening were found highly susceptible in greenhouse with both inoculums.

12 genotypes showed presence of only one gene. 4 genotypes (IR87759-7-1-2-3, IR88964-112-2-3, Jumli Marshi/IR64//Jumli Marshi -5 and Jumli Marshi/IR64//Jumli Marshi -21) showed the presence of only Xa4 gene specified by MP marker. Likewise, the number of genotypes that showed the presence of only Xa5 gene were 5(IR88960-22-1-1-1, Chhomrong, Lumle-2, Jumli Marshi/ IR64//Jumli Marshi-7 and Jumli Marshi/IR64//Jumli Marshi -25) and Xa7 were 3 (Sankarika, Jumli Marshi/IR64//Jumli Marshi-13 and Jumli Marshi/IR64//Jumli Marshi -15). 
A. Acharya, N. R. Adhikari, R.B. Amgain, A. Poudel, R. Yadav and K. Poudyal

Table 3: Status of bacterial blight genes in rice genotypes and their response in greenhouse

\begin{tabular}{|c|c|c|c|c|c|c|c|c|}
\hline \multirow[b]{2}{*}{ S.N. } & \multirow{2}{*}{$\begin{array}{l}\text { Rice Line/Name of } \\
\text { genotypes }\end{array}$} & \multicolumn{2}{|c|}{ MP (150 bp) } & \multirow{2}{*}{$\begin{array}{l}\text { RM } 122 \\
\text { (227bp) } \\
\text { locus } \\
1(227 \\
\text { bp) }\end{array}$} & \multirow{2}{*}{$\begin{array}{c}\text { M5 } \\
\text { (294 bp) } \\
\text { locus } \\
1(294 \\
\text { bp) }\end{array}$} & \multirow{2}{*}{$\begin{array}{c}\text { pTA } 248 \\
(1000 \mathrm{bp}) \\
\begin{array}{c}\text { locus } \\
1(1000 \mathrm{bp})\end{array}\end{array}$} & \multicolumn{2}{|c|}{ BB Score } \\
\hline & & $\begin{array}{l}\text { locus } \\
1(150 \\
\text { bp) }\end{array}$ & $\begin{array}{c}\text { locus } \\
2(120 \\
\text { bp) }\end{array}$ & & & & Inoculum-1 & Inoculum-2 \\
\hline 1. & IR83383-B-B-141-1 & 1 & 0 & 1 & 0 & 0 & $\mathrm{R}$ & $\mathrm{R}$ \\
\hline 2. & IR88969-11-2-2-1 & 1 & 0 & 1 & 0 & 0 & $\mathrm{R}$ & $\mathrm{R}$ \\
\hline 3. & IR88869-2-2-2-2 & 1 & 0 & 1 & 0 & 0 & $\mathrm{R}$ & $\mathrm{R}$ \\
\hline 4. & IR87684-1-18-1-2-3 & 0 & 0 & 0 & 0 & 0 & $\mathrm{~S}$ & $\mathrm{~S}$ \\
\hline 5. & IR64683-87-2-2-3-3 & 0 & 0 & 0 & 0 & 0 & HS & HS \\
\hline 6. & IR87761-28-1-1-3 & 1 & 0 & 1 & 0 & 0 & $\mathrm{R}$ & $\mathrm{R}$ \\
\hline 7. & IR87759-7-1-2-3 & 1 & 0 & 0 & 0 & 0 & $\mathrm{R}$ & $\mathrm{R}$ \\
\hline 8. & IR88966-45-2-1-3 & 0 & 0 & 0 & 0 & 0 & HS & HS \\
\hline 9. & IR88965-38-2-2-4 & 0 & 0 & 0 & 0 & 0 & HS & HS \\
\hline 10. & IR84852-B-12-2-3 & 1 & 0 & 0 & 1 & 0 & MS & $\mathrm{S}$ \\
\hline 11. & IR88964-11-2-2-3 & 1 & 0 & 0 & 0 & 0 & $\mathrm{R}$ & $\mathrm{R}$ \\
\hline 12. & IR88965-36-4-1-1 & 0 & 0 & 0 & 0 & 0 & MR & MR \\
\hline 13. & IR86857-46-1-1-3 & 0 & 0 & 0 & 0 & 0 & HS & HS \\
\hline 14. & IR88960-22-1-1-1 & 0 & 0 & 1 & 0 & 0 & $\mathrm{R}$ & $\mathrm{R}$ \\
\hline 15. & Jumli Marshi & 0 & 0 & 0 & 0 & 0 & HS & HS \\
\hline 16. & IR87759-6-1-3-1 & 1 & 0 & 1 & 0 & 0 & $\mathrm{R}$ & $\mathrm{R}$ \\
\hline 17. & IR87761-66-2-2-3 & 1 & 0 & 1 & 0 & 0 & $\mathrm{R}$ & $\mathrm{R}$ \\
\hline 18. & IR88839-3-1-2-2 & 1 & 0 & 1 & 0 & 0 & $\mathrm{R}$ & $\mathrm{R}$ \\
\hline 19. & IR83383-B-B-140-4 & 1 & 0 & 1 & 0 & 0 & $\mathrm{R}$ & $\mathrm{R}$ \\
\hline 20. & IR74371-70-1-1 & 0 & 0 & 0 & 0 & 0 & $\mathrm{~S}$ & HS \\
\hline 21. & IR88965-39-1-6-4 & 0 & 0 & 0 & 0 & 0 & HS & HS \\
\hline 22. & Sunaulo Sugandha & 0 & 0 & 0 & 0 & 0 & $\mathrm{~S}$ & HS \\
\hline 23. & Radha-11 & 0 & 0 & 0 & 0 & 0 & HS & HS \\
\hline 24. & Chhomrong & 0 & 0 & 1 & 0 & 0 & $\mathrm{R}$ & $\mathrm{R}$ \\
\hline 25. & Lumle-2 & 0 & 0 & 1 & 0 & 0 & $\mathrm{R}$ & $\mathrm{R}$ \\
\hline 26. & Macchapuchre-3 & 0 & 0 & 0 & 0 & 0 & HS & HS \\
\hline 27. & Sankarika & 0 & 0 & 0 & 0 & 0 & HS & HS \\
\hline 28. & Masuli & 0 & 0 & 0 & 0 & 0 & HS & HS \\
\hline 29. & Loktantra & 1 & 0 & 1 & 0 & 0 & $\mathrm{R}$ & $\mathrm{R}$ \\
\hline 30. & IRBB-60 & 1 & 0 & 1 & 0 & 1 & $\mathrm{R}$ & $\mathrm{R}$ \\
\hline 31. & Khumal-4 & 1 & 0 & 0 & 1 & 0 & $\mathrm{R}$ & $\mathrm{R}$ \\
\hline 32. & NR11297-B-B & 0 & 0 & 1 & 1 & 0 & $\mathrm{R}$ & $\mathrm{R}$ \\
\hline 33. & NR11335-B-B & 0 & 0 & 1 & 1 & 0 & $\mathrm{R}$ & $\mathrm{R}$ \\
\hline 34. & NR11298-B-B & 0 & 0 & 1 & 1 & 0 & $\mathrm{R}$ & $\mathrm{R}$ \\
\hline 35. & NR11334-B-B & 1 & 0 & 0 & 1 & 0 & $\mathrm{R}$ & $\mathrm{R}$ \\
\hline 36. & NR11328-B-B & 1 & 0 & 1 & 0 & 0 & $\mathrm{R}$ & $\mathrm{R}$ \\
\hline 37. & NR11329-B-B & 1 & 0 & 1 & 1 & 0 & $\mathrm{R}$ & $\mathrm{R}$ \\
\hline 38. & IR71033-4-1-127-B & 0 & 0 & 0 & 0 & 0 & MR & MR \\
\hline 39. & $\begin{array}{l}\text { Jumli Marshi/IR 64//Jumli } \\
\text { Marshi -3 }\end{array}$ & 1 & 0 & 0 & 1 & 0 & $\mathrm{~S}$ & $\mathrm{~S}$ \\
\hline 40. & $\begin{array}{l}\text { Jumli Marshi/IR 64//Jumli } \\
\text { Marshi -4 }\end{array}$ & 1 & 0 & 1 & 0 & 0 & MR & MR \\
\hline 41. & $\begin{array}{l}\text { Jumli Marshi/IR 64//Jumli } \\
\text { Marshi -5 }\end{array}$ & 1 & 0 & 0 & 0 & 0 & $\mathrm{R}$ & $\mathrm{R}$ \\
\hline
\end{tabular}




\begin{tabular}{|c|c|c|c|c|c|c|c|c|}
\hline \multirow[b]{2}{*}{ S.N. } & \multirow{2}{*}{$\begin{array}{l}\text { Rice Line/Name of } \\
\text { genotypes }\end{array}$} & \multicolumn{2}{|c|}{ MP (150 bp) } & \multirow{2}{*}{$\begin{array}{c}\text { RM } 122 \\
(227 \mathrm{bp})\end{array}$} & \multirow{2}{*}{$\begin{array}{c}\text { M5 } \\
\text { (294 bp) } \\
\text { locus } \\
1(294 \\
\text { bp) }\end{array}$} & \multirow{2}{*}{$\begin{array}{c}\text { pTA } 248 \\
(1000 \mathrm{bp}) \\
\text { locus } \\
1(1000 \mathrm{bp})\end{array}$} & \multicolumn{2}{|c|}{ BB Score } \\
\hline & & $\begin{array}{c}\text { locus } \\
1(150 \\
\text { bp) }\end{array}$ & $\begin{array}{c}\text { locus } \\
2(120 \\
\text { bp) }\end{array}$ & & & & Inoculum-1 & Inoculum-2 \\
\hline 42. & $\begin{array}{l}\text { Jumli Marshi/IR 64//Jumli } \\
\text { Marshi -6 }\end{array}$ & 0 & 0 & 0 & 0 & 0 & HS & HS \\
\hline 43. & $\begin{array}{l}\text { Jumli Marshi/IR 64//Jumli } \\
\text { Marshi -7 }\end{array}$ & 0 & 0 & 1 & 0 & 0 & $\mathrm{R}$ & $\mathrm{R}$ \\
\hline 44. & $\begin{array}{l}\text { Jumli Marshi/IR 64//Jumli } \\
\text { Marshi -8 }\end{array}$ & 0 & 0 & 0 & 0 & 0 & HS & HS \\
\hline 45. & $\begin{array}{l}\text { Jumli Marshi/IR 64//Jumli } \\
\text { Marshi -9 }\end{array}$ & 0 & 0 & 0 & 0 & 0 & HS & HS \\
\hline 46. & IR 64 & 0 & 0 & 0 & 0 & 0 & HS & HS \\
\hline 47. & $\begin{array}{l}\text { Jumli Marshi/IR 64//Jumli } \\
\text { Marshi -10 }\end{array}$ & 0 & 0 & 0 & 0 & 0 & HS & HS \\
\hline 48. & $\begin{array}{l}\text { Jumli Marshi/IR 64//Jumli } \\
\text { Marshi -11 }\end{array}$ & 1 & 1 & 1 & 0 & 0 & $\mathrm{R}$ & $\mathrm{R}$ \\
\hline 49. & $\begin{array}{l}\text { Jumli Marshi/IR 64//Jumli } \\
\text { Marshi -12 }\end{array}$ & 1 & 1 & 1 & 0 & 0 & $\mathrm{R}$ & $\mathrm{R}$ \\
\hline 50. & $\begin{array}{l}\text { Jumli Marshi/IR 64//Jumli } \\
\text { Marshi -13 }\end{array}$ & 0 & 0 & 0 & 1 & 0 & HS & HS \\
\hline 51. & $\begin{array}{l}\text { Jumli Marshi/IR 64//Jumli } \\
\text { Marshi -14 }\end{array}$ & 1 & 0 & 0 & 1 & 0 & $\mathrm{R}$ & $\mathrm{R}$ \\
\hline 52. & $\begin{array}{l}\text { Jumli Marshi/IR 64//Jumli } \\
\text { Marshi -15 }\end{array}$ & 0 & 0 & 0 & 1 & 0 & $\mathrm{R}$ & $\mathrm{R}$ \\
\hline 53. & $\begin{array}{l}\text { Jumli Marshi/IR 64//Jumli } \\
\text { Marshi -16 }\end{array}$ & 0 & 0 & 0 & 0 & 0 & $\mathrm{R}$ & $\mathrm{R}$ \\
\hline 54. & $\begin{array}{l}\text { Jumli Marshi/IR 64//Jumli } \\
\text { Marshi -17 }\end{array}$ & 0 & 0 & 0 & 0 & 0 & HS & HS \\
\hline 55. & $\begin{array}{l}\text { Jumli Marshi/IR 64//Jumli } \\
\text { Marshi -18 }\end{array}$ & 0 & 0 & 0 & 0 & 0 & HS & HS \\
\hline 56. & $\begin{array}{l}\text { Jumli Marshi/IR 64//Jumli } \\
\text { Marshi -19 }\end{array}$ & 0 & 0 & 0 & 0 & 0 & HS & HS \\
\hline 57. & $\begin{array}{l}\text { Jumli Marshi/IR 64//Jumli } \\
\text { Marshi -20 }\end{array}$ & 1 & 1 & 1 & 1 & 0 & $\mathrm{R}$ & $\mathrm{R}$ \\
\hline 58. & $\begin{array}{l}\text { Jumli Marshi/IR 64//Jumli } \\
\text { Marshi -21 }\end{array}$ & 1 & 1 & 0 & 0 & 0 & $\mathrm{R}$ & $\mathrm{R}$ \\
\hline 59. & $\begin{array}{l}\text { Jumli Marshi/IR 64//Jumli } \\
\text { Marshi -22 }\end{array}$ & 0 & 0 & 0 & 0 & 0 & MS & MS \\
\hline 60. & $\begin{array}{l}\text { Jumli Marshi/IR 64//Jumli } \\
\text { Marshi -23 }\end{array}$ & 1 & 1 & 1 & 1 & 0 & $\mathrm{R}$ & $\mathrm{R}$ \\
\hline 61. & $\begin{array}{l}\text { Jumli Marshi/IR 64//Jumli } \\
\text { Marshi -24 }\end{array}$ & 0 & 0 & 0 & 1 & 0 & HS & HS \\
\hline 62. & $\begin{array}{l}\text { Jumli Marshi/IR 64//Jumli } \\
\text { Marshi -25 }\end{array}$ & 0 & 0 & 1 & 0 & 0 & $\mathrm{R}$ & $\mathrm{R}$ \\
\hline
\end{tabular}

$* 1=$ present, $0=$ absent

Genotypes showing the presence of only Xa4 gene by SSR marker MP1 were found susceptible in greenhouse, whereas, genotypes showing the presence of Xa5 gene only were all found resistant in greenhouse. Genotypes that showed the presence of Xa7 gene only, two genotypes were found susceptible in greenhouse. Rice genotype (IR84852-B-12-2-3) showed moderately susceptible reaction on inoculum-1 and susceptible reaction for inoculum-2. It showed the presence of both 
Xa4 gene and Xa7 gene as identified by markers. Genotypes (Sunaulo Sugandha) and (IR7437170-1-1) also showed differential responses to sources of inoculum, susceptible for inoculum-1 and highly susceptible for inoculum-2. Rice genotype (Jumli Marshi/IR 64//Jumli Marshi-4) that showed the presence of Xa4 and Xa5 gene as amplified by their specific SSR markers shows moderately resistant reaction for both inoculums in greenhouse conditions. Same is the case for (Jumli Marshi/ IR 64//Jumli Marshi-3) as it showed the presence of Xa4 and Xa7 but rendered susceptible for both inoculums. On the other hand, (IR88965-36-4-1-1) and (IR71033) were found resistant in greenhouse conditions but no presence of any gene by markers. Avirulent gene in bacteria exhibits the specificity for resistance gene in the rice plant. Some resistance genes are effective only in adult plants, while others are effective at all stages of growth. Some genes confer resistance to a broad spectrum of Xanthomonas races, whereas others do so against only one or a few races. This observation could be influenced by particular geographical locations (Lui et al., 2007). Disease resistant system is controlled by the developmental control which has been observed in other plant-pathogen systems. Some rice resistance genes are expressed at the adult stage at highest level. Xa7 gene shows broad resistance in adult stages of plant while Xa21 mediated resistance increases progressively from susceptible juvenile stage to full resistance at the later adult stage (Khush et al., 1978). However, xa5 appears to be the effective gene at all growth stages as it can confer resistance and exhibit a broad spectrum of resistance to Xanthomomas isolates throughout Asia. The cultivars containing a single major resistance gene proved susceptible due to pathogen mutation. Genotypes which showed the presence of more than one gene were found resistant in greenhouse conditions. Recently, pyramiding of more than one major resistance gene has been proven to deliver durable resistance against BB (Rajpurohit et al., 2010).

Table 4: Response of genotypes having only one gene in greenhouse

\begin{tabular}{|c|c|c|c|c|c|}
\hline Only Xa4 & & Only Xa5 & & Only Xa7 & \\
\hline Genotypes & $\begin{array}{l}\text { BB } \\
\text { Score }\end{array}$ & Genotypes & $\begin{array}{l}\text { BB } \\
\text { Score }\end{array}$ & Genotypes & $\begin{array}{l}\text { BB } \\
\text { Score }\end{array}$ \\
\hline IR87759-7-1-2-3 & HS & IR88960-22-1-1-1 & $\mathrm{R}$ & Sankarika & HS \\
\hline IR88964-11-2-2-3 & HS & Chhomrong & $\mathrm{R}$ & $\begin{array}{l}\text { JumliMarshi/IR64// } \\
\text { JumliMarshi -13 }\end{array}$ & HS \\
\hline $\begin{array}{l}\text { JumliMarshi/IR64// } \\
\text { JumliMarsh-5 }\end{array}$ & HS & Lumle-2 & $\mathrm{R}$ & $\begin{array}{l}\text { JumliMarshi/IR64// } \\
\text { JumliMarshi -15 }\end{array}$ & $\mathrm{R}$ \\
\hline \multirow[t]{2}{*}{$\begin{array}{l}\text { JumliMarshi/IR64// } \\
\text { JumliMarshi-21 }\end{array}$} & MS & JumliMarshi/IR64//JumliMarshi -7 & $\mathrm{R}$ & & \\
\hline & & JumliMarshi/IR64//JumliMarshi -25 & $\mathrm{R}$ & & \\
\hline
\end{tabular}

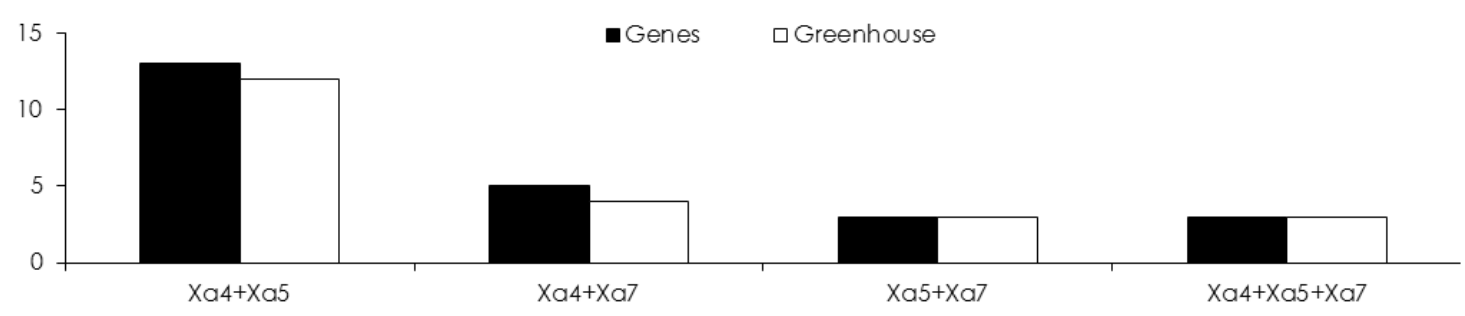

Figure 1: Number of genotypes showing presence of more than one gene by markers and their resistance in greenhouse conditions 


\section{CONCLUSION}

Bacterial leaf blight of rice is a major disease of the world and is more prone to South Asia. Rice being the major crop in case of Nepal, it deems necessary for its management. Screening of sixty rice genotypes using markers revealed the genotypes which showed the presence of different genes in them, highest number showing the presence of Xa4 gene followed by Xa5 gene and Xa7 gene respectively. Among genotypes containing the BB resistance, gene Xa5 only was found all resistant in greenhouse suggesting Xa5 gene effectiveness in the study with two inoculums used. IRBB 60, resistant check, was only genotype that showed the presence of Xa21 gene which can be used as source for breeding for BB resistance. Genotypes having more than one BB resistance gene were found resistant in greenhouse conditions with both inoculums suggesting combination of BB resistance gene through gene pyramiding will provide BB resistant varieties in rice breeding.

\section{ACKNOWLEDGEMENT}

This research was conducted under the financial support of National Agriculture Research and Development Fund (NARDF). Sincere acknowledgement is extended to the Biotechnology division, NARC, Lalitpur for providing access to the laboratory, seed materials and for creating the healthy office environment for conducting the experiment successfully.

\section{REFERENCES CITED}

Adhikari, T. B., \& Mew, T. W. (1999). Reaction of rice cultivars to different inoculum densities of Xanthomonas oryzae pv. oryzae in Nepal. Phytopathology, 82: 1153.

Bhasin, H., Bhatia, D., Raghuvanshi, S., Lore, J. S., Sahi, G. K., Kaur, B., Bikal Y., \& Singh, K. (2012). New PCR-based sequence-tagged site marker for bacterial blight resistance gene Xa38 of rice. Molecular breeding, 30(1), 607-611.

Chen, X., Temnykh, S., Xu, Y., Cho, Y. G., \& McCouch, S. R. (1997). Development of a microsatellite framework map providing genome-wide coverage in rice (Oryza sativa L.). Theoretical and applied genetics, 95(4), 553-567.

Exconde, O.R. (1993). Yield losses due to bacterial leaf blight of rice. Philippines Agriculture 57: 128-140.

Huang, N., Angeles, E. R., Domingo, J., Magpantay, G., Singh, S., Zhang, G., Kumaravadivel, N., Bennett, J., \& Khush, G. S. (1997). Pyramiding of bacterial blight resistance genes in rice: marker-assisted selection using RFLP and PCR. Theoretical and Applied Genetics, 95(3), 313320.

IRRI. 1996. International Rice Research Institute, Rice disease in North and eastern India, Nepal, Bangladesh with focus on bacterial leaf blight. International rice research institute, Los Banos, Philippines.

Ma, B., Wang, W., Zhao, B., Zhou, Y., Zhu, L., \& Zhai, W. (1999). Studies of PCR marker for the rice bacterial blight resistance gene Xa-4. Hereditas, 21(3), 9-12.

McCouch, S. R., Teytelman, L., Xu, Y., Lobos, K. B., Clare, K., Walton, M., \& Zhang, Q. (2002). Development and mapping of 2240 new SSR markers for rice (Oryza sativa L.). DNA research, 9(6), 199-207.

Porter, B. W., Chittoor, J. M., Yano, M., Sasaki, T., \& White, F. F. (2003). Development and mapping of markers linked to the rice bacterial blight resistance gene Xa7. Crop science, 43(4), 14841492. 
Rajpurohit, D., Kumar, R., Kumar, M., Paul, P., Awasthi, A., Basha, P. O., Puri, A., Jhang, T., Singh, K., \& Dhaliwal, H. S. (2011). Pyramiding of two bacterial blight resistance and a semidwarfing gene in Type 3 Basmati using marker-assisted selection. Euphytica, 178(1), 111-126.

Sidhu, G. S., \& Khush, G. S. (1978). Dominance reversal of a bacterial blight resistance gene in some rice cultivars. Phytopathology, 68(3), 461-463.

Singh, S., Sidhu, J. S., Huang, N., Vikal, Y., Li, Z., Brar, D. S., Dhaliwal, H.S., \& Khush, G. S. (2001). Pyramiding three bacterial blight resistance genes (xa5, xa13 and Xa21) using markerassisted selection into indica rice cultivar PR106. Theoretical and Applied Genetics, 102(6-7), 1011-1015.

Sul, I. W., \& Korban, S. S. (1996). A highly efficient method for isolating genomic DNA from plant tissues. Plant Tissue Culture and Biotechnology, 2, 113-116.

Swings, J., Van den Mooter, M., Vauterin, L., Hoste, B., Gillis, M., Mew, T. W., \& Kersters, K. (1990). Reclassification of the Causal Agents of Bacterial Blight (Xanthomonas campestris pv. oryzae) and Bacterial Leaf Streak (Xanthomonas campestris pv. oryzicola) of Rice as Pathovars of Xanthomonas oryzae (ex Ishiyama 1922) sp. nov., nom. rev. International Journal of Systematic and Evolutionary Microbiology, 40(3), 309-311. 